Article

\title{
Biotransformation of geniposide in Gardenia jasminoides to genipin by Trichoderma harzianum CGMCC 2979
}

\author{
Yuesheng Dong a,*, Leping Liu a, Yongming Bao a, Aiyu Hao ${ }^{\mathrm{b}}$, Ying Qina ${ }^{\mathrm{a}}$, Zujia Wen ${ }^{\mathrm{a}}$, Zhilong Xiu ${ }^{\mathrm{a}}$ \\ a School of Life Science and Biotechnology, Dalian University of Technology, Dalian 116024, Liaoning, China \\ b Dalian Institute for Drug Control, Dalian 116021, Liaoning, China
}

A R T I C L E I N F O

Article history:

Received 14 February 2014

Accepted 4 April 2014

Published 20 September 2014

Keywords:

Geniposide

Genipin

Trichoderma harzianum

Biotransformation

Geniposide- $\beta$-glucosidase

Purification

\section{Introduction}

Genipin and its glycoside, geniposide, constitute the chief active components of the fruits of Gardenia jasminoides (G. jasminoides). These plants have been used in traditional Chinese medicine to treat inflammation, jaundice, and hepatic diseases. Geniposide is thought to achieve most of its biological activities through genipin [1]. Recent studies have demonstrated that genipin possesses numerous pharmacological activities, such as protection against oxidative damage, as well as hypoglycemic, hepatoprotection, cytotoxic, anti-inflammatory, and fibrinolytic activities [2-4]. Genipin has also become a compound of interest because it is a naturally occurring cross-linking agent, allowing it to form networks with important biological polymers, such as gelatin, collagen, and chitosan. Genipin exhibits a cross-linking property comparable to chemical cross-linking agents such as glutaraldehyde, but with a toxicity that is about 10000 times less. Genipin has been regarded as a potential substitute for synthetic cross-linkers in the preparation of scaffolds for tissue engineering and drug carriers for enhanced delivery [5-7]. In addition, genipin is colorless, but it can react spontaneously with amino acids or some proteins to form dark blue pigments with luminescence characteristics, and this property of genipin has enabled its usage as a potential finger-mark reagent [8].

The enormous demand for genipin means that its production requires a simple and low-cost process. However, the content of genipin in gardenia fruits is rather low (about

\footnotetext{
* Corresponding author. Tel/Fax: +86-411-84706344; E-mail: yshdong@dlut.edu.cn This work was Supported by the National Natural Science Foundation of China (81172966), the National Basic Research Program of China (973 Program, 2009CB724706), and the Fundamental Research Funds for the Central Universities (DUT12ZD209). 
$0.005 \%-0.01 \%$ ), although the content of geniposide is high (about 3\%-8\%). Direct extraction of genipin from gardenia fruits through the use of acid hydrolysis is not suitable because iridoid glycosides are unstable in the presence of acid. The current production of genipin usually involves the use of an enzyme or microorganism to transform geniposide to genipin. Gong et al. [9] isolated a $\beta$-glucosidase, which displayed avid affinity and high catalytic efficiency for geniposide, from Aspergillus niger Au0847. Winotapun et al. [10] used commercial cellulase to catalyze simultaneous cell disruption and conversion of released geniposide to genipin. Fu et al. [11] transformed pure geniposide with Aspergillus awamori FYS-9, and the conversion of geniposide could reach $97.7 \%$. However, in such methods, pure enzyme or geniposide need to be purified or purchased, which leads to a complex and expensive process. Furthermore, some commercial $\beta$-glucosidases have been reported to react with genipin to form blue pigment that displays a maximum absorbance around $580 \mathrm{~nm}$ without necessarily achieving a high yield of genipin [12,13].

Some attempts have been made to improve the method and reduce the cost of genipin preparation. Direct biotransformation of the raw herb by microorganisms, a new method that has the benefit of low cost and simple operation, has been successfully used in our laboratory to transform piceid in Polygonum cuspidatum to resveratrol using Aspergillus oryzae and to transform steroidal saponins in Dioscorea zingiberensis $\mathrm{CH}$ Wright to diosgenin using A. oryzae and Trichoderma harzianum (T. harzianum) $[14,15]$. Although the production of genipin from geniposide via biotransformation of the raw herb by Penicillium nigricans has been reported for $G$. jasminoides; with a geniposide-to-genipin conversion rate as high as 95\%, the fermentation time is still too long (108 h) [16]. Furthermore, the conversion rate in that particular study was calculated from the reduction of geniposide, and no information was given regarding the yield of genipin in the biotransformation. This information is important for evaluating the practicality of the method. In addition, the study did not provide any information regarding the enzymes involved in the transformation. It is necessary to study the key enzymatic reaction associated with the biotransformation of the raw herb because understanding the mechanism of the biotransformation will help us design a better system.

During the course of screening for a fungal strain capable of converting geniposide to genipin in G. jasminoides, T. harzianum CGMCC 2979 was identified as the strain that could produce the highest level of genipin by direct biotransformation of the raw herb [16]. In this paper, the fermentation conditions for T. harzianum CGMCC 2979 were optimized and the purification of genipin from the fermentation broth was described (Scheme 1). In addition, a specific geniposide- $\beta$-glucosidase produced by T. harzianum during the fermentation process was also isolated, purified, and characterized.

\section{Experimental}

\subsection{Materials and chemicals}

All experiments were performed in triplicate. Data shown

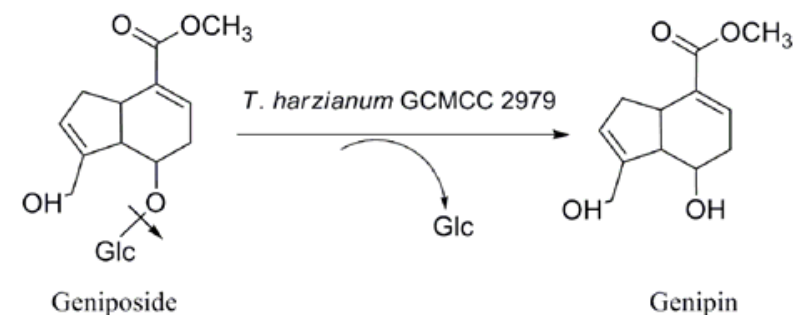

Scheme 1. Biotransformation of geniposide to genipin by Trichoderma harzianum CGMCC 2979.

are the means of the triplicate experiments.

The dry fruits of $G$. jasminoides (DFA) were purchased from Anguo (Baoding, China). The fruits were ground into a powder, passed through a 60-mesh sieve, and then used directly for biotransformation. Geniposide and genipin standards (purities > 98.5\%) were obtained from the National Pharmaceutical Engineering Center for Solid Preparation in Chinese Herbal Medicine (Nanchang, China). Protein markers for SDS-PAGE were purchased from Takara Co. (Otsu, Japan). Zingibernsis newsaponin, deltonin, diosgenin-triglucoside, and diosgenin-diglucoside standards (purities > 98\%) were prepared as described previously [17]; diosgenin standard (purity > 98\%) was obtained from Sigma Chemical Co. (St. Louis) and trillin (purity $>$ 98\%) was obtained from Wuhu Delta Pharmaceutical Co. (Wuhu, China). Polymeric adsorbent XAD-16N and silica gel were the products of Rohm and Hass Co. (Philadelphia) and Qingdao Haiyang Chemical Co. (Qingdao, China), respectively. DEAE Sepharose $^{\mathrm{Tm}}$ and Superdex 200 were purchased from GE Healthcare Biosciences (Pittsburgh). $p$-Nitrophenyl $\beta$-D-glucopyranoside (PNPG) was obtained from Shanghai Baoman Life Technology Co. Ltd (Shanghai, China). HPLC-grade acetonitrile was purchased from TEDIA (Cincinnati). All other chemicals used were of analytical grade. T. harzianum used as the transformation strain was previously isolated from a soil sample obtained locally. The organism is now preserved in the China General Microbiological Culture Collection Center (Beijing, China) with the number CGMCC 2979.

\subsection{Analytical methods}

HPLC was carried out using a Waters 600E Multi-solvent Delivery System connected to a 7725i injector and coupled to a UV detector (Model 2487, Waters Corporation, Milford). Analysis of geniposide and genipin was performed with a Sunfire $\mathrm{C}_{18}$ column (150 mm $\times 4.6 \mathrm{~mm} \times 5 \mu \mathrm{m}$, Waters Corporation) at room temperature. The compounds were eluted from the column with a solution of acetonitrile/water $(15: 85 \mathrm{v} / \mathrm{v})$ at a flow rate of $1 \mathrm{~mL} / \mathrm{min}$ and detected by absorbance at $238 \mathrm{~nm}$. The retention times of geniposide and genipin were 6.14 and $12.45 \mathrm{~min}$, respectively. The steroidal saponins and their transformation products were analyzed by an established method [18]. The separation of steroidal saponins was performed on the same column as geniposide and genipin using acetonitrile (A) and water (B) as the mobile phase under the following gradient program with a flow rate of $1.0 \mathrm{~mL} / \mathrm{min}$ : 
0-14 $\min , 44 \% \quad A \rightarrow 75 \%$ A; $14-15 \min , 75 \% \quad A \rightarrow 91 \%$ A; 15-32 $\min , 91 \% \mathrm{~A}$. The column effluent was monitored at the UV wavelength of $203 \mathrm{~nm}$, and the retention times of zingibernsis newsaponin, deltonin, diosgenin-triglucoside, diosgenin-diglucoside, trillin, and diosgenin were 7.40, 8.95, 10.10, $11.87,15.40$, and $30.04 \mathrm{~min}$, respectively.

The concentration of protein was measured by the Bradford method using bovine serum albumin as the standard. $\beta$-Glucosidase activity was determined by a colorimetric method using PNPG as a substrate [19]. One unit of enzyme activity was defined as the amount of enzyme that liberates $1 \mu \mathrm{mol}$ of $p$-nitrophenol per hour. $\beta$-Glucosidase activity toward geniposide was determined as follows: $0.2 \mathrm{~mL}$ of a solution of 1 $\mathrm{mg} / \mathrm{mL}$ geniposide was incubated with $0.2 \mathrm{~mL}$ enzyme solution for $2 \mathrm{~h}$, and the sample was boiled for $5 \mathrm{~min}$ to stop the reaction. The reaction product was detected by HPLC as described above. The molecular weight of the enzyme was estimated by SDS-PAGE and further determined by mass spectrometry using a MALDI/TOF spectrometer (MALDI micro MX, Waters Corporation). The MS and NMR spectra were collected by a triple quadrupole mass spectrometer (Finnigan TSQ, Thermo Electron Corporation, Waltham) and 400M NMR Spectrometer (INOVA 400, Varian Corporation, Palo Alto), respectively.

\subsection{Extraction of geniposide and genipin}

About 3.0 g DFA powder was accurately weighed and separately extracted with $100 \mathrm{~mL}$ of each aqueous ethanol solution $(0,20 \%, 50 \%, 70 \%$, and $100 \%)$ at ambient temperature for 12 h. Soxhlet extraction of DFA powder with $20 \%$ aqueous ethanol was also carried out over a period of $4 \mathrm{~h}$. Each extract was filtered and analyzed by HPLC. In order to verify that the extraction rate of genipin at the optimal ethanol concentration (established for the extraction of DFA powder), about $4 \mathrm{mg}$ standard genipin was accurately weighed and dissolved in $1 \mathrm{~mL}$ ethanol solution, and the concentration of genipin was analyzed by HPLC to calculate the extraction rate of genipin.

\subsection{Culture and optimization of culture conditions}

Unless indicated, all liquid cultures were prepared in 250-mL Erlenmeyer flasks. Well-developed fungal spores were collected from T. harzianum CGMCC 2979 grown on potato dextrose agar, and suspended in sterile water. The spore suspension was inoculated into $50 \mathrm{~mL}$ medium containing $40 \mathrm{~g} / \mathrm{L}$ DFA. The culture was incubated on a rotary shaker at $30^{\circ} \mathrm{C}$ and $150 \mathrm{r} / \mathrm{min}$ for $24 \mathrm{~h}$, and $2 \mathrm{~mL}$ of this seed culture was used to inoculate $50 \mathrm{~mL}$ fresh fermentation medium. The fermentation medium contained only DFA plus water or DFA plus sodium phosphate buffer with a DFA concentration of $40 \mathrm{~g} / \mathrm{L}$. Both the seed medium and fermentation medium were sterilized at $121{ }^{\circ} \mathrm{C}$ for $20 \mathrm{~min}$ before inoculation to prevent microorganism contamination from DFA. Every $4 \mathrm{~h}, 1 \mathrm{~mL}$ of culture was sampled, and cells were diluted in $0.4 \%$ trypan blue solution and counted in a hemocytometer to assess the rate of dead blue cells from the total number of cells counted. The $\beta$-glucosidase activity of the culture was measured, and the colony morphology of the culture was also compared with that of a pure culture of T. harzianum CGMCC 2979. After $96 \mathrm{~h}$ of incubation, $12.5 \mathrm{~mL}$ of ethanol was added to the fermentation broth, and the mixture was placed at room temperature for $12 \mathrm{~h}$. The mixture was then filtered, and the filtrate was subjected to HPLC analysis.

To maximize the yield of genipin, factors that may influence the conversion rate (including fermentation time, FDA concentration, $\mathrm{pH}$, and fermentation temperature) were optimized. The fermentation time was set at 12 to $120 \mathrm{~h}$. The effects of different concentrations of DFA $(40,60,80,100$, and $120 \mathrm{~g} / \mathrm{L})$ and fermentation temperatures $\left(25,30\right.$, and $\left.37^{\circ} \mathrm{C}\right)$ were also investigated. The effect of $\mathrm{pH}$ was determined by adjusting the medium to the desired $\mathrm{pH}$ ( $\mathrm{pH} 2.1$ to 7.1 ) with $66.7 \mathrm{mmol} / \mathrm{L}$ phosphate buffer.

The yield of genipin and the percentage of conversion rate are given by the following formulae:

Yield (mg/g) = genipin content (mg)/DFA raw herb (g) (1) Conversion rate $(\%)=$ content of genipin $(\mathrm{mol}) /$ initial content

$$
\text { of geniposide }(\mathrm{mol}) \times 100 \%
$$

\subsection{Separation and purification of genipin in the fermentation broth}

To investigate the efficiency associated with the removal of residual geniposide in the product of biotransformation, the fermentation broth was collected after $45 \mathrm{~h}$ of fermentation. Ethanol was added to the fermentation broth to give a final concentration of $20 \%(\mathrm{v} / \mathrm{v})$, and the mixture was centrifuged at $10000 \times g$ for $20 \mathrm{~min}$ to remove the biomass. The supernatant was collected and designated as the 45 -h sample to distinguish it from another sample taken after $48 \mathrm{~h}$ of fermentation. The sample contained $2.4 \mathrm{mg} / \mathrm{mL}$ genipin and $0.9 \mathrm{mg} / \mathrm{mL}$ geniposide, as determined by HPLC analysis. It was then subjected to XAD-16N-resin and silica-gel chromatography.

The resins were soaked in 95\% ethanol, shaken for $24 \mathrm{~h}$, and then thoroughly washed with distilled water. The adsorption condition for XAD-16N chromatography was tested as follows: eight $10-\mathrm{mL}$ aliquots of the above 45 -h sample were adjusted to $\mathrm{pH} 2.0-9.0$, and each was added to a separate 50-mL flask. To each flask, $1 \mathrm{~g}$ of hydrated XAD-16N resin was added, and the flasks were shaken at $130 \mathrm{r} / \mathrm{min}$ on a rotary shaker for $12 \mathrm{~h}$ at $25{ }^{\circ} \mathrm{C}$. After adsorption, the liquid fraction was discarded; the resin was washed with distilled water, soaked in $10 \mathrm{~mL} \mathrm{80 \%}(\mathrm{v} / \mathrm{v})$ ethanol, and shaken for another 12 $\mathrm{h}$ at the same temperature and speed. The ethanol solution was removed, and the concentrations of genipin and geniposide in the ethanol solution collected from each of the 8 flasks were measured to determine the amounts of genipin and geniposide desorbed from XAD-16N. The adsorption capacity $\left(q_{\mathrm{e}}\right)$ of XAD-16N was calculated according to the following equation [20]:

$$
q_{\mathrm{e}}=\left(C_{0}-C_{\mathrm{e}}\right) \times V_{\mathrm{i}} /((1-M) \times W)
$$

where $C_{0}$ is the initial concentration $(\mathrm{mg} / \mathrm{mL})$ of genipin, $C_{\mathrm{e}}$ is the concentration $(\mathrm{mg} / \mathrm{mL})$ of genipin at equilibrium, $V_{\mathrm{i}}$ is the volume of the initial sample solution ( $\mathrm{mL}$ ), $M$ is the water content, which was $65 \%$ as determined by a published method [20], and $W$ is the weight of resin (g). 
The effect of the ethanol concentration on the ratio of genipin desorption was determined using a glass column $(2.1 \mathrm{~cm} \times$ $15 \mathrm{~cm}$ ) packed with $45 \mathrm{~g} \mathrm{XAD}-16 \mathrm{~N}$ (wet resin). The bed volume of the resin was $50 \mathrm{~mL} .100 \mathrm{~mL}$ of the 45 -h sample was adjusted to $\mathrm{pH} 4.0$ and then applied to the column. After the adsorption reached saturation, the column was washed with three bed volumes of distilled water and then eluted with a stepwise gradient of increasing ethanol concentrations $(30 \%, 40 \%, 50 \%$, $60 \%, 70 \%, 80 \%, 90 \%$, and $100 \%$ ) using $100 \mathrm{~mL}$ for each concentration. The eluent was monitored by HPLC.

The silica gel-chromatography step was carried out in a glass column $(2.1 \mathrm{~cm} \times 24 \mathrm{~cm})$ packed with $40 \mathrm{~g}$ of silica gel. 30 $\mathrm{mL}$ of the 45-h sample was concentrated to dryness under vacuum, and about $50 \mathrm{mg}$ of this residue was loaded onto the silica gel column. The column was eluted with solutions containing different ratios of chloroform to methanol $(85: 15$, $84: 16,83: 17$, and $82: 18, v / v$ ), and the eluent was collected and monitored by HPLC.

The purification of genipin was also scaled up to $200 \mathrm{~mL}$ using fermentation broth taken after $48 \mathrm{~h}$ of fermentation, the time point at which the maximal geniposide-to-genipin conversion rate was detected. The sample was extracted with $50 \mathrm{~mL}$ ethanol for $12 \mathrm{~h}$. After centrifugation at $10000 \times \mathrm{g}$ for $20 \mathrm{~min}$, $240 \mathrm{~mL}$ supernatant was recovered. The supernatant, which contained $2.6 \mathrm{mg} / \mathrm{mL}$ genipin and $0.09 \mathrm{mg} / \mathrm{mL}$ geniposide (as determined by HPLC), was designated as the 48-h sample. It was adjusted to $\mathrm{pH} 4.0$ and then applied to a column $(3.0 \mathrm{~cm} \times$ $30 \mathrm{~cm}$ ) packed with $145 \mathrm{~g}$ XAD-16N resin. The column was first washed with two bed volumes of $30 \%(\mathrm{v} / \mathrm{v})$ ethanol in water ( $\mathrm{pH} 4.0$ ), followed by elution with two bed volumes of $60 \%$ $(v / v)$ ethanol in water ( $\mathrm{pH}$ 6.5). The eluent, which contained genipin as detected by UV absorbance, was concentrated to dryness under vacuum and loaded onto a column $(4.0 \mathrm{~cm} \times 25 \mathrm{~cm})$ packed with $150 \mathrm{~g}$ silica gel. The column was eluted with $600 \mathrm{~mL}$ chloroform-methanol $(83: 17, v / v)$ solution. The eluent containing genipin was concentrated to dryness and then resuspended in $2.0 \mathrm{~mL} 66.7 \%$ methanol in water to give pure genipin.

\subsection{Purification of $\beta$-glucosidase}

Culture acquired from fermentation under the optimized conditions was centrifuged at $10000 \times g$ for $10 \mathrm{~min}$ to remove the cells. Solid $\left(\mathrm{NH}_{4}\right)_{2} \mathrm{SO}_{4}$ was slowly added to the supernatant while stirring to $75 \%$ saturation and was then stored at $4{ }^{\circ} \mathrm{C}$ overnight. The mixture was centrifuged at $10000 \times g$ for $10 \mathrm{~min}$ to collect the protein precipitate. This crude protein was dissolved in $66.7 \mathrm{mmol} / \mathrm{L}$ sodium phosphate buffer ( $\mathrm{pH} \mathrm{5.0)}$, and the insoluble material was removed by centrifugation $(10000 \times g$ for $10 \mathrm{~min}$ ). The supernatant was passed through a $0.45-\mu \mathrm{m}$ membrane, and a portion of the pigment present in it was removed by ultrafiltration. The sample was loaded onto a DEAE Sepharose $^{\mathrm{TM}}$ column $(3.0 \mathrm{~cm} \times 12 \mathrm{~cm})$ pre-equilibrated with $66.7 \mathrm{mmol} / \mathrm{L}$ sodium phosphate buffer ( $\mathrm{pH}$ 5.0) at a flow rate of $1 \mathrm{~mL} / \mathrm{min}$. The flow-through fraction was concentrated by ultrafiltration and then applied to a Superdex 200 column $(3.0 \mathrm{~cm} \times 21 \mathrm{~cm})$ pre-equilibrated with $66.7 \mathrm{mmol} / \mathrm{L}$ sodium phosphate buffer ( $\mathrm{pH}$ 5.0). The column was eluted with the same buffer at a flow rate of $1 \mathrm{~mL} / \mathrm{min}$. All chromatographic runs were monitored for the presence of protein at $280 \mathrm{~nm}$, and all of the fractions collected were assayed for $\beta$-glucosidase activity. Active fractions were pooled and stored at $4{ }^{\circ} \mathrm{C}$ for further analysis.

\subsection{Enzyme properties}

The effect of temperature on enzyme activity was determined for a temperature range of $20-70{ }^{\circ} \mathrm{C}$, and the effect of $\mathrm{pH}$ was investigated with a $\mathrm{pH}$ range of 3.0-8.0 using $66.7 \mathrm{mmol} / \mathrm{L}$ sodium phosphate buffer adjusted to the desired $\mathrm{pH}$. The visible spectrum from 500 to $800 \mathrm{~nm}$ was scanned to monitor the production of byproduct (blue pigment).

Substrate specificity was tested with geniposide from $G$. jasminoides and steroidal saponins from D. zingiberensis, including zingibernsis newsaponin, deltonin, diosgenin-triglucoside, diosgenin-diglucoside and trillin. Substrate solution was prepared by dissolving $1 \mathrm{mg}$ geniposide or steroidal saponin in $1 \mathrm{~mL} 66.7 \mathrm{mM}$ sodium phosphate buffer ( $\mathrm{pH} 5.0$ ), and 0.2 $\mathrm{mL}$ of the purified enzyme solution was then added to the same volume of substrate. For steroidal saponins, the reaction was carried out at $50{ }^{\circ} \mathrm{C}$ for $24 \mathrm{~h}$. After that, $0.2 \mathrm{~mL}$ butanol was added to the reaction mixture and vortexed for $1 \mathrm{~min}$, and the reaction product was then extracted with butanol and detected by HPLC. For geniposide, the reaction was also carried out at $50{ }^{\circ} \mathrm{C}$, but for different periods of time (1.0, 1.5, 2.0, 2.5, and $3.0 \mathrm{~h})$, and the reaction was terminated by boiling in water for $5 \mathrm{~min}$.

The $K_{\mathrm{m}}$ and $V_{\max }$ values of the purified geniposide- $\beta$ - glucosidase were determined from a Lineweaver-Burk plot of the substrate-saturation curve obtained with a geniposide concentration range of 1.18 to $2.95 \mathrm{mmol} / \mathrm{L}$ at $\mathrm{pH} 5.0$ and $50{ }^{\circ} \mathrm{C}$.

\section{Results and discussion}

\subsection{Determination of geniposide content in DFA and effect of ethanol concentration on geniposide yield}

When geniposide was extracted directly from DFA by soxhlet's extraction, a content of $64.1 \pm 1.5 \mathrm{mg} / \mathrm{g}$ was obtained, and this was taken as the content of the geniposide in DFA. To determine the contents of genipin and geniposide more efficiently, the effect of ethanol on the extraction yields of geniposide and genipin was also investigated. Because geniposide is mainly present in the solid matter of the fruit and genipin is secreted into the supernatant after biotransformation [16], DFA and standard genipin were selected as the materials for extraction. With $0,20 \%, 50 \%, 70 \%$, and $100 \%$ ethanol, the yields of geniposide from DFA were $55.4 \pm 0.8,63.8 \pm 2.4,61.9 \pm$ $2.9,51.6 \pm 0.5$, and $26.8 \pm 1.3 \mathrm{mg} / \mathrm{g}$ DFA, respectively. The highest yield was obtained with $20 \%$ ethanol, and this was almost the same as the yield obtained by the Soxhlet extraction. The extraction of standard genipin achieved a rate of $99.4 \% \pm$ $0.2 \%$ when the concentration of genipin in the sample was $4 \mathrm{mg} / \mathrm{mL}$ and the concentration of ethanol was $20 \%$. Samples that were taken at the pre-biotransformation and post-biotransformation stages were treated by adding ethanol to a final 
concentration of $20 \%$ and then stored for further analysis.

\subsection{Biotransformation of geniposide in $G$. jasminoides by $T$. harzianum CGMCC 2979}

DFA powder was incubated with the fungus at $30^{\circ} \mathrm{C}$ for $96 \mathrm{~h}$ with shaking at $150 \mathrm{r} / \mathrm{min}$. A comparison of the content of substrate with that of product at the pre-biotransformation and post biotransformation stages showed that geniposide was transformed into genipin at a conversion rate of $93 \%$. Thus, genipin could be obtained from the bioconversion of DFA, dispensing with the use of purified enzyme and extraction of geniposide from the raw material. During fermentation, $\beta$-glucosidase was secreted by T. harzianum CGMCC 2979 to hydrolyze the geniposide in DFA, producing glucose as one of the byproducts. The glucose produced was further used as a carbon source for the growth of the fungus, thereby reducing the feedback inhibition caused by glucose and increasing the efficiency of the biotransformation. To obtain a higher yield of genipin in a shorter period of time, the fermentation conditions were further optimized. The result of the temperature-effect experiment showed that, at the end of fermentation, the conversion rates of genipin obtained at 25,30 , and $37{ }^{\circ} \mathrm{C}$ were $92.6 \% \pm 3.7 \%$, 97.7\% $\pm 0.9 \%$, and $88.6 \% \pm 2.2 \%$, respectively. Various groups also have reported that $30{ }^{\circ} \mathrm{C}$ is the optimum temperature for culturing T. harzianum [15,21]. Thus, the production of genipin by $T$. harzianum appeared to be dependent on the growth conditions of the fungus.

The concentration of DFA in the culture also had a significant effect on the conversion rate (Fig. 1(a)). The conversion rate of genipin exceeded $95 \%$ for DFA concentrations ranging from 40 to $80 \mathrm{~g} / \mathrm{L}$. However, when the concentration of DFA exceeded $80 \mathrm{~g} / \mathrm{L}$, the conversion rate of genipin declined dramatically.

The $\mathrm{pH}$ of the medium also affected the conversion rate significantly. The conversion rate was less than $60 \%$ when the $\mathrm{pH}$ of the medium was kept at 2.1 to 5.1 , but it reached $98.3 \% \pm$ $3.1 \%$ when the $\mathrm{pH}$ was increased to 6.1 , and then the conversion rate decreased again when the $\mathrm{pH}$ was further increased to 7.1 (Fig. 1(b)). These data indicated that $\mathrm{pH} 6.1$ was the best $\mathrm{pH}$ for the fungus to produce the enzyme needed to convert geniposide to genipin. The optimum conversion rate at $\mathrm{pH} 6.1$ could also be attributed to the presence of sodium phosphate salt, which provided a source of phosphorus and acted as a buffering agent to stabilize the $\mathrm{pH}$ of the culture, facilitating both $T$. harzianum growth and enzyme secretion.

The optimized culture conditions were as follows: $80 \mathrm{~g} / \mathrm{L}$ DFA at $30{ }^{\circ} \mathrm{C}$ and $\mathrm{pH}$ 6.1. No additional carbon or nitrogen source was necessary for the fermentation, which made the process simple and efficient. A time course experiment with the above conditions showed that the conversion rate of genipin increased quickly from 24 to $48 \mathrm{~h}$; the concentration of geniposide was $13.2 \mathrm{mmol} / \mathrm{L}$ before biotransformation and decreased constantly as the fermentation progressed, leading to a dramatic decline after $40 \mathrm{~h}$ of fermentation. At $48 \mathrm{~h}$, a maximum genipin level of $12.9 \mathrm{mmol} / \mathrm{L}$ or $3.0 \mathrm{~g} / \mathrm{L}$ was attained, which was about 1.88 times higher than that obtained from Penicillium nigricans biotransformation $(6.88 \mathrm{mmol} / \mathrm{L}, 1.6 \mathrm{~g} / \mathrm{L})$. The conversion rate and yield reached $97.8 \%$ and $3.6 \mathrm{mg} / \mathrm{g}$ DFA, respectively (Fig. 2). Therefore, $48 \mathrm{~h}$ was regarded as the best fermentation time for genipin production, and this was $55.6 \%$ shorter than the fermentation time stated in a previous study [16]. Beyond $48 \mathrm{~h}$, the conversion rate decreased gradually $(91.4 \% \pm 1.3 \%$ at $50 \mathrm{~h}, 85.5 \% \pm 4.8 \%$ at $52 \mathrm{~h}$, and $83.6 \% \pm$ $3.3 \%$ at $55 \mathrm{~h}$ ).

The trypan blue exclusion experiment showed that the rate of fungal cell death was lower than $10.0 \%$ during the first $32 \mathrm{~h}$, and then it increased to $13.0 \%$ at $40 \mathrm{~h}, 16.6 \%$ at $48 \mathrm{~h}$, and finally to $25.0 \%$ at the end of the fermentation (55 h). The time course experiment showed that $\beta$-glucosidase activity was first detected at $12 \mathrm{~h}$, reached a maximun at $40 \mathrm{~h}(23.77 \mathrm{U} / \mathrm{mL})$, and then gradually decreased to $19.76 \mathrm{U} / \mathrm{mL}$ at $55 \mathrm{~h}$ (Fig. 2). The colony morphology of the culture was identical to that of the pure culture of T. harzianum CGMCC 2979. These data suggested that the $\beta$-glucosidase, which transformed geniposide to genipin in gardenia fruits, was produced by $T$. harzianum CGMCC 2979, and the decrease in $\beta$-glucosidase activity after $40 \mathrm{~h}$ of fermentation was partially caused by fungal cell death.

\subsection{Separation and purification of genipin in the fermentation} broth

The static adsorption experiment showed that genipin could be adsorbed to XAD-16N, and the adsorption capacity was af-
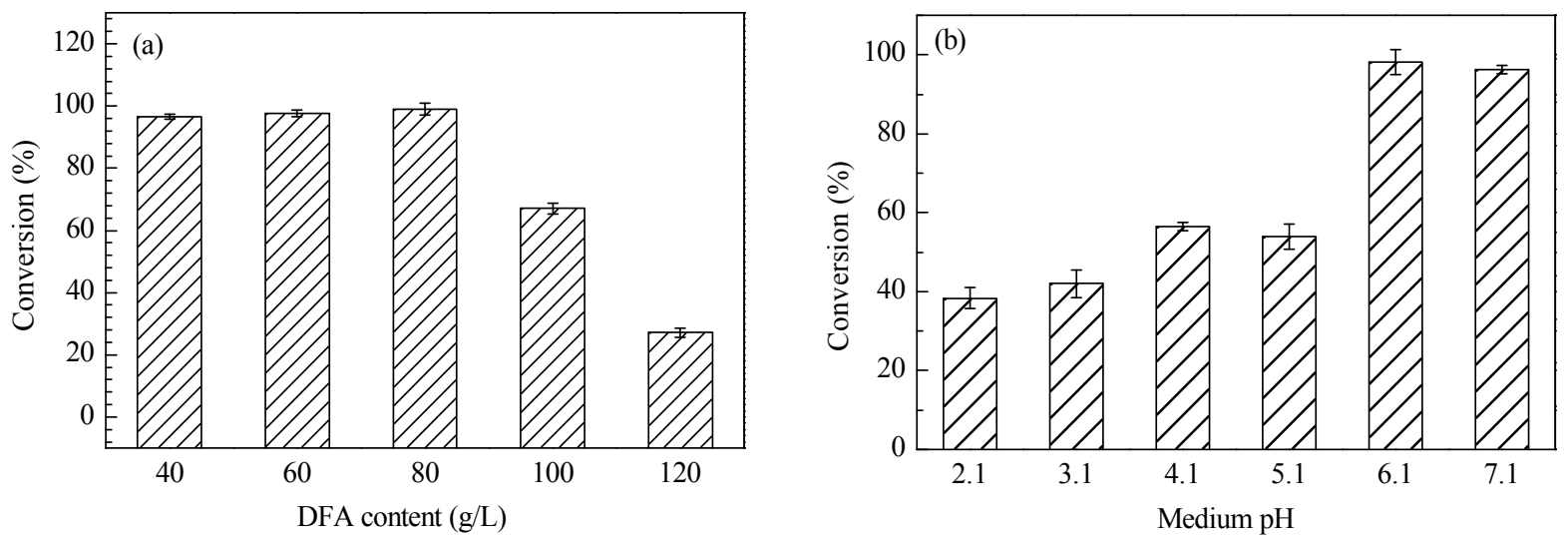

Fig. 1. Effects of dry fruits of Gardenia jasminoides (DFA) content (a) and medium pH (b) on the geniposide-to-genipin conversion rate. 


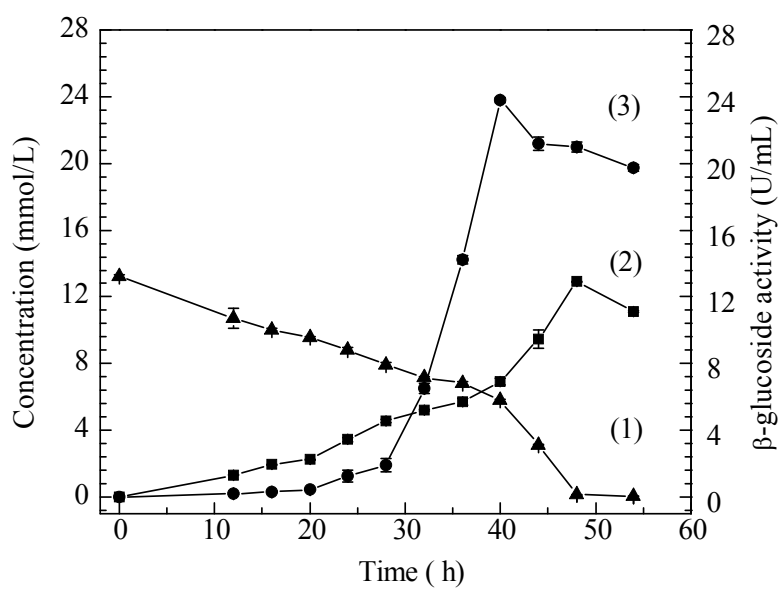

Fig. 2. Time course biotransformation of geniposide (1) in G. jasminoides into genipin (2) by $T$. harzianum and $\beta$-glucosidase activity of the culture (3).

fected by the initial $\mathrm{pH}$ of the sample. When the initial $\mathrm{pH}$ of the supernatant increased from 2.0 to 7.0, the $q_{\mathrm{e}}$ of genipin for XAD-16N increased with $\mathrm{pH}$ up to 4.0 , and then it decreased slightly with further increases in $\mathrm{pH}$; when the $\mathrm{pH}$ was greater than 7.0, no genipin was detected in the eluent, suggesting that $\mathrm{pH}=4$ was the best for genipin to adsorb to XAD-16N. The $q_{\mathrm{e}}$ of geniposide remained constant at about $3.2 \mathrm{mg} / \mathrm{g}$ resin (Fig. $3(\mathrm{a})$ ).

The best condition for eluting genipin from the XAD-16N resins was determined by eluting the adsorbed genipin with a stepwise gradient of increasing ethanol concentrations. Dynamic desorption curves showed that the genipin concentration in the eluent increased with increasing ethanol concentrations in the eluting solvent, reaching a maximum when the eluting solvent contained 50\% $(\mathrm{v} / \mathrm{v})$ ethanol, but the concentration started to decrease when the ethanol concentration in the solvent was further increased. Because the geniposide was eluted by a low ethanol concentration (Fig. 3(b)), the column was first washed with $30 \%$ ethanol, and elution followed with $60 \%$ ethanol. The yields of genipin and geniposide were $92.2 \%$ and $32.7 \%$, respectively. These data indicated that most of the geniposide could not adsorb to XAD-16N in the presence of $20 \%(\mathrm{v} / \mathrm{v})$ ethanol and $\mathrm{pH} 4.0$, and it could be removed from the resin during the washing step, which used $30 \%(v / v)$ ethanol in water at $\mathrm{pH} 4.0$.

Because of the complicated mixture of components in the fermentation broth, the separation of genipin and geniposide from the other components in the clarified broth (after extraction with ethanol) was also carried out by silica-gel chromatography. Genipin that was adsorbed to the silica gel was thoroughly eluted by 83:17 ( $\mathrm{v} / \mathrm{v})$ methanol-chloroform, while the adsorbed geniposide was eluted by 82:18 (v/v) chloroform-methanol. Thus, 83:17 ( $v / v)$ chloroform-methanol was chosen as the best eluting solvent.

Genipin was successfully separated and purified from the fermentation broth that was collected at the point of the highest geniposide-to-genipin conversion rate (48 h). The separation and purification of genipin was achieved using the optimized XAD-16N-resin chromatography method combined with silica-gel chromatography. The unconverted geniposide, pigment, and other impurities in the fermentation broth were effectively removed, yielding $389.0 \mathrm{mg}$ colorless genipin with a purity of $98.3 \%$ from $200 \mathrm{~mL}$ culture broth (by HPLC analysis). The yields of genipin that were achieved by the individual purification methods were 87.1\% (XAD-N16) and 77.0\% (silica gel), whereas the yield obtained from the combined method was $62.3 \%$.

MS analysis of the purified product in negative mode produced two ion peaks, one at 225 and the other at 261, representing $[\mathrm{M}-\mathrm{H}]^{-}$and $[\mathrm{M}+\mathrm{Cl}]^{-}$, respectively. Thus, the molecular weight of the purified product was 226, which was consistent with the molecular weight of genipin. The NMR data revealed the following: ${ }^{1} \mathrm{H}$ NMR $\left(\mathrm{CH}_{3} \mathrm{OD}\right) \delta: 7.53(\mathrm{~s}, \mathrm{H}-3), 5.83(\mathrm{~s}, \mathrm{H}-7)$, 4.80 (d, $J=8.4 \mathrm{~Hz}, \mathrm{H}-1$ ), 4.32 (d, $J=14.4 \mathrm{~Hz}, \mathrm{H}-10 \mathrm{a}), 4.22$ (d, $J=$ $14.4 \mathrm{~Hz}, \mathrm{H}-10 \mathrm{~b}), 3.70\left(\mathrm{~s},-\mathrm{OCH}_{3}\right), 3.16(\mathrm{~m}, \mathrm{H}-5), 2.86(1 \mathrm{H}, \mathrm{m}$, H-6b), 2.50 (1H, m, H-9), and 2.06 (1H, m, H-6a); ${ }^{13} \mathrm{C}$ NMR (400 $\mathrm{MHz}, \mathrm{CH}_{3} \mathrm{OD}$ ) $\delta: 170.0$ (-CO2-), 154.4 (C-3), 145.7 (C-8), 128.4 (C-7), 111.9 (C-4), 97.9 (C-1), $61.8(\mathrm{C}-10), 51.8\left(-\mathrm{OCH}_{3}\right), 48.6$ (C-9), 40.1 (C-6), and 37.8 (C-5). All of these findings were in accordance with those of genipin reported by Kim et al. [4].

To our knowledge, the biotransformation of $G$. jasminoides

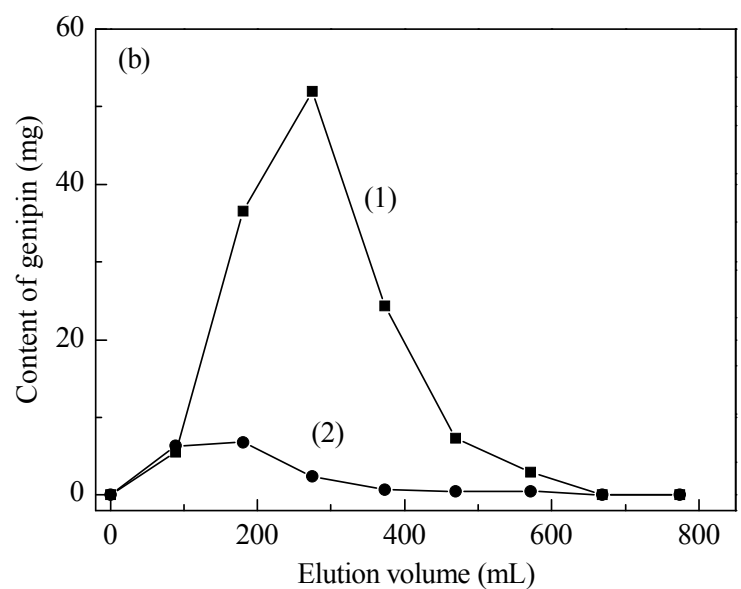

Fig. 3. Separation and purification of genipin and geniposide by XAD-16N-resin chromatography. (a) Static adsorption capacity for genipin and geniposide; (b) Dynamic desorption curves for genipin (1) and geniposide (2). 
by T. harzianum CGMCC 2979 achieved the shortest fermentation time, highest geniposide-to-genipin conversion rate, and highest concentration of genipin compared with other reported methods for genipin production via raw herb biotransformation. This biotransformation of G. jasminoides using T. harzianum CGMCC 2979, together with the high selectivity between genipin and geniposide in their adsorption to XAD-16N resin and silica gel, would offer an alternative method for producing genipin with high yield and high purity.

\subsection{Purification and enzymatic characteristics of geniposide- $\beta$-glucosidase}

To study the enzymatic characteristics of geniposide- $\beta$ glucosidase, the enzyme was purified by a method that combined ammonium sulfate precipitation with DEAE Sepharose $\mathrm{e}^{\mathrm{TM}}$ chromatography and Superdex 200 chromatography. The flow-through at the DEAE Sepharose ${ }^{\mathrm{TM}}$ step contained $\beta$-glucosidase activity, while most of the pigment in the preparation remained bound to the column. Further chromatography of the unbound fraction on the Superdex-200 column yielded a purified enzyme, achieving a 16-fold purification and a yield of about $14.7 \%$. Using PNPG as a substrate, the specific activity of the purified geniposide- $\beta$-glucosidase was determined to be $72.0 \mathrm{U} / \mathrm{mg}$ protein. The purification results are summarized in Table 1.

The molecular weight of the purified enzyme estimated by SDS-PAGE was $76.5 \mathrm{kDa}$ (Fig. 4), but MALDI/TOF MS analysis gave a lower value, $74.4 \mathrm{kDa}$. This enzyme was smaller than the geniposide-hydrolyzing $\beta$-glucosidases that were isolated from a human intestinal anaerobe and A. niger Au0847, which have molecular weights of 90 and $230 \mathrm{kDa}$, respectively [9, 22].

The geniposide- $\beta$-glucosidase that was purified from T. harzianum showed maximum activity within the $\mathrm{pH}$ range of 4.0-5.0. The geniposide-to-genipin conversion rate was above $90 \%$ at $\mathrm{pH} 6.0$, but it dropped to $70 \%$ at $\mathrm{pH} 7.0$. The activity of this geniposide- $\beta$-glucosidase gradually increased with temperature, peaking at $50{ }^{\circ} \mathrm{C}$ and sharply decreasing at $60^{\circ} \mathrm{C}$. The enzyme lost all activity at $70{ }^{\circ} \mathrm{C}$. A time course experiment showed that genipin appeared mainly after $40 \mathrm{~h}$ of fermentation (Fig. 2), and this was also the time at which the maximum level of $\beta$-glucosidase activity was detected. These data indicated that that $0-40 \mathrm{~h}$ was the period of enzyme production, and 40-48 h was the period of biotransformation. During the period of biotransformation, increasing the fermentation temperature will shorten the time of biotransformation and increase the produce yield [14]. The time course data, together with higher catalytic activity at $40-50{ }^{\circ} \mathrm{C}$, suggested that the fermentation time of geniposide could be further shortened by

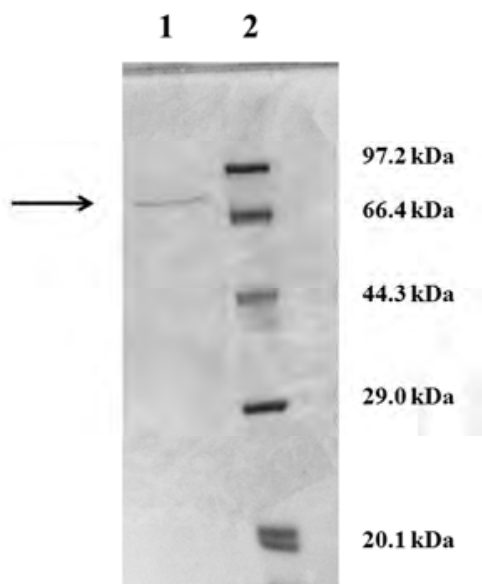

Fig. 4. SDS-PAGE of geniposide-B-glucosidase. Lane 1, purified geniposide-B-glucosidase; Lane 2, protein markers.

increasing the fermentation temperature to $40-50{ }^{\circ} \mathrm{C}$ during the period of biotransformaiton. This would improve the efficiency of the biotransformation.

The purified enzyme showed considerable activity toward geniposide, converting $91.0 \%$ and $98.9 \%$ of it to genipin, after 1 and $2 \mathrm{~h}$ of incubation at $50{ }^{\circ} \mathrm{C}$ and $\mathrm{pH} 5.0$, respectively. The $K_{\mathrm{m}}$ and $V_{\max }$ values of the purified enzyme for geniposide were $3.6 \mathrm{mmol} / \mathrm{L}$ and $775 \mu \mathrm{mol} / \mathrm{h} / \mathrm{mg}$ protein, respectively. $(y=$ $\left.0.00467 x+0.00129, R^{2}=0.9746\right)$. The $K_{\mathrm{m}}$ value of the purified geniposide- $\beta$-glucosidase in this work was comparable to that from A. niger Au0847 (2.93 mmol/L) [9]. However, the purified enzyme could not hydrolyze the $\alpha-(1 \rightarrow 2)$-rhamnoside of zingibernsis newsaponin and deltonin and the $\beta-(1 \rightarrow 3)$ - and $\beta$ - $(1 \rightarrow 4)$-glucosides of steroidal saponins, including zingibernsis newsaponin, deltonin, diosgenin-triglucoside, and diosgenin-diglucoside. It could not hydrolyze trillin, which is also a mono $\beta$-1-4 glycosidic saponin with different aglycones. These data suggested that the purified enzyme was a specific geniposide- $\beta$-glucosidase, and it could probably recognize the aglycone of geniposide. A $\beta$-glucosidase from $T$. harzianum with a similar molecular weight $(75 \mathrm{kDa})$ has also been reported, and the substrate specificity of the enzyme has been determined using aryl-glycosides, disaccharides, and some oligosaccharides as substrates. However, the catalytic activity of the enzyme with respect to natural products has not been reported [23].

The absorption spectra of the pre- and post-enzymatic hydrolysate at 500 to $800 \mathrm{~nm}$ were compared, and no distinct change was observed. These data suggested that the purified geniposide- $\beta$-glucosidase did not react with genipin. This property of the enzyme may be one of the reasons for the high geniposide-to-genipin conversion rate in the biotransformation of raw herb.

Table 1

Purification of geniposide- $\beta$-glucosidase.

\begin{tabular}{lccccc}
\hline Step & Total activity* $(\mathrm{U})$ & Total protein $(\mathrm{mg})$ & Specific activity $(\mathrm{U} / \mathrm{mg})$ & Yield (\%) & Purification factor \\
\hline $\mathrm{NH}_{4} \mathrm{SO}_{4}$ precipitation & 196.0 & 28.5 & 6.8 & 100 & - \\
DEAE sepharose & 109.8 & 12.3 & 8.9 & 56.0 & 1.3 \\
Superdex-200 & 28.8 & 0.4 & 72.0 & 14.7 & 10.6 \\
\hline
\end{tabular}

* Activity was measured with PNPG as a substrate. 


Graphical Abstract
Chin. J. Catal., 2014, 35: 1534-1546 doi: 10.1016/S1872-2067(14)60134-0
Biotransformation of geniposide in Gardenia jasminoides to genipin by Trichoderma harzianum CGMCC 2979
Yuesheng Dong*, Leping Liu, Yongming Bao, Aiyu Hao, Ying Qin, Zujia Wen, Zhilong Xiu
Dalian University of Technology; Dalian Institute for Drug Control
We described a simple and effective method for preparing genipin based on the biotransformation of geniposide in Gardenia jasminoides
by Trichoderma harzianum. The mechanism of biotransformation was also discussed.

\section{Conclusions}

We have described a simple and effective method for preparing genipin based on the biotransformation of geniposide in G. jasminoides by T. harzianum CGMCC 2979. Genipin produced from the biotransformation of geniposide was extracted from the fermentation broth (harvested after $48 \mathrm{~h}$ of fermentation, the optimum time of conversion) with XAD-16N resin and subsequently purified by silica-gel chromatography, yielding a total recovery of $62.3 \%$ and a purity of $98.3 \%$. Compared with previously reported methods, this new method achieved the shortest fermentation time, highest geniposide-to-genipin conversion rate, and genipin concentration. In addition, a pure geniposide- $\beta$-glucosidase, which showed a high level of specific activity toward geniposide, was purified and characterized. This simple and efficient biotransformation of geniposide in $G$. jasminoides to genipin by T. harzianum CGMCC 2979 could be considered as a promising alternative method for practical production of genipin for various applications.

\section{References}

[1] Jeon W K, Hong H Y, Kim B C. Arch Biochem Biophys, 2011, 512: 119

[2] Koo H J, Lim K H, Jung H J, Park E H.J Ethnopharmacol, 2006, 103: 496

[3] Zhang C Y, Parton L E, Ye C P, Krauss S, Shen R C, Lin C T, Porco J A, Lowell B B. Cell Metab, 2006, 3: 417

[4] Kim S J, Kim J K, Lee D U, Kwak J H, Lee S M. Eur J Pharmacol, 2010, 635: 188

[5] Bi L, Cao Z, Hu Y Y, Song Y, Yu L, Yang B, Mu J H, Huang Z S, Han Y
S. J Mater Sci-Mater Med, 2011, 22: 51

[6] Liang H Z, Chen H, Wang J F, He Y L. Adv Mater Res, 2011, 236: 1793

[7] Haag J, Baiguera S, Jungebluth P, Barale D, Del Gaudio C, Castiglione F, Bianco A, Comin C E, Ribatti D, Macchiarini P. Biomaterials, 2012, 33: 780

[8] Jelly R, Patton E L T, Lennard C, Lewis S W, Lim K F. Anal Chim Acta, 2009, 652: 128

[9] Gong G H, Zheng Z M, Liu H, Wang L, Diao J S, Wang P, Zhao G H. J Microbiol Biotechnol, 2014, 24: 788

[10] Winotapun W, Opanasopit P, Ngawhirunpat T, Rojanarata T. Enzyme Microb Technol, 2013, 53: 92

[11] Fu Y S, Zhang P, Chen C. J Beijing Univ Chem Technol (Natur Sci) (付 岩帅, 张鹏, 陈畅. 北京化工大学学报(自然科学版)), 2011, 38: 81

[12] Yang Y S, Zhang T, Yu S C, Ding Y, Zhang L Y, Qiu C, Jin D. Molecules, 2011, 16: 4295

[13] Lee S W, Lim J M, Bhoo S H, Paik Y S, Hahn T R. Anal Chim Acta, 2003, 480: 267

[14] Liu L, Dong Y S, Qi S S, Wang H, Xiu Z L. Appl Microbiol Biotechnol, 2010, 85: 933

[15] Xu M M, Sun Q Su J, Wang J F, Xu C, Zhang T, Sun Q L. Enzyme Microb Technol, 2008, 42: 440

[16] Wang H, Liu L, Guo Y X, Dong Y S, Zhang D J, Xiu Z L. Appl Microbiol Biotechnol, 2007, 75: 763

[17] Dong Y S, Teng H, Qi S S, Liu L, Wang H, Zhao Y K, Xiu Z L. Biochem Eng J, 2010, 52: 123

[18] Qi S S, Dong Y S, Zhao Y K, Xiu Z L. Chromatographia, 2009, 69: 865

[19] Zhang C Z, Yu H S, Bao Y M, An L J, Jin F X. Chem Pharm Bull, 2001, 49: 795

[20] Jia G J, Lu X Y.J Chromatogr A, 2008, 1193: 136

[21] Seyis I, Aksoz N. Int Biodeterior Biodegrad, 2005, 55: 115

[22] Yang L, Akao T, Kobashi K. Biol Pharm Bull, 1995, 18: 1175

[23] Yun S I, Jeong C S, Chung D K, Choi H S. Biosci biotechnol biochem, 2001, 65: 2028

\title{
哈茨木霉CGMCC 2979生物转化枚子中的京尼平苷制备京尼平
}

\author{
董悦生 ${ }^{\mathrm{a},{ }^{*}}$, 刘乐平 ${ }^{\mathrm{a}}$, 包永明 ${ }^{\mathrm{a}}$, 郝爱鱼 ${ }^{\mathrm{b}}$, 秦 莹 $^{\mathrm{a}}$, 温祖佳 ${ }^{\mathrm{a}}$, 修志龙 ${ }^{\mathrm{a}}$ \\ ${ }^{\mathrm{a}}$ 大连理工大学生命科学与技术学院, 辽宁大连 116024 \\ ${ }^{\mathrm{b}}$ 大连市药品检验所, 辽宁大连 116021
}


摘要: 采用微生物直接转化药材的方法, 将㭛子中的京尼平苷转化为京尼平, 无需糖苷酶和京尼平苷的制备. 在培养温度为 $30^{\circ} \mathrm{C}$, $\mathrm{pH}$ 6.1 以及㭛子载量为 $80 \mathrm{~g} / \mathrm{L}$ 的条件下, $48 \mathrm{~h}$ 京尼平苷的转化率为 $97.8 \%$. 转化后的京尼平通过XAD-16N大孔树脂偶联硅胶层析 的方法, 制备得到纯度大于 $95 \%$ 的京尼平, 收率为 $62.3 \%$. 在催化、转化机制研究中, 从哈茨木霸CGMCC 2979 的发酵液中分离得到 了分子量为 $74.4 \mathrm{kDa}$ 的京尼平苷 $\beta$-葡萄糖苷酶, 该酶最优催化条件为 $50{ }^{\circ} \mathrm{C}$ 和 $\mathrm{pH} 4.0-5.0 . K_{\mathrm{m}}$ 和 $V_{\max }$ 分别为 $3.6 \mathrm{mmol} / \mathrm{L}$ 和 $775 \mu \mathrm{mol} /$ $\mathrm{h} / \mathrm{mg}$ 蛋白. 本文提供了一种简便、高效制备京尼平的新方法.

关键词: 京尼平苷; 京尼平; 哈茨木霖; 生物转化; 京尼平苷 $\beta$-葡萄糖苷酶; 纯化.

收稿日期: 2014-02-14. 接受日期: 2014-04-04. 出版日期: 2014-09-20.

*通讯联系人. 电话/传真：(0411)84706344; 电子信箱：yshdong@dlut.edu.cn

基金来源：国家自然科学基金(81172966); 国家重点基础研究发展计划(973计划, 2009CB724706); 中央高校基本科研业务费专项 资金资助(DUT12ZD209).

本文的英文电子版由Elsevier出版社在ScienceDirect上出版(http://www.sciencedirect.com/science/journal/18722067).

\section{1. 前言}

枙子作为一种传统的中药, 被广泛用于炎症和黄疸 型肝炎的治疗. 京尼平与其糖苷-京尼平苷是秨子果实 的主要活性成分, 其中京尼平是最主要的活性成分, 京 尼平苷通过转化为京尼平发挥作用 ${ }^{[1]}$. 近年的研究 ${ }^{[2-4]}$ 表 明京尼平具有广泛的药理活性, 如抗氧化、降血糖、保 肝、细胞毒, 抗炎以及纤溶活性等; 同时它还是一种天然 的交联剂, 备受关注. 和其他化学交联剂(如戊二醛)相 比, 京尼平的交联能力相当, 能够和很多重要的生物聚 合物如明胶、胶原, 壳聚糖交联, 但毒性要比戊二醛低 10000 倍, 所以京尼平也是一种合成交联剂的理想替代 物, 在组织工程和药物载体领域发挥重要作用 ${ }^{[5-7]}$. 此 外, 京尼平虽是一种无色物质, 但是能够与氨基酸和一 些蛋白形成发光的蓝黑色素, 京尼平的这个特征, 能够 有望使之用于指纹鉴别领域 ${ }^{[8]}$.

京尼平需求量大, 要求其制备过程简便低廉. 但是 京尼平在枚子果实中的含量很低, 只占 $0.005 \%-0.01 \%$, 而京尼平苷的含量却很高, 约占 $3 \%-8 \%$. 直接提取法并 不适合从栃子中制备京尼平, 该方法需要利用酸将京尼 平苷水解为京尼平, 但京尼平苷属环烯醚萜苷, 在酸中 不稳定, 收率很低. 目前制备京尼平的方法主要是用酶 或者微生物水解京尼平苷的糖苷键, 使之转化为京尼平. Gong 等 ${ }^{[9]}$ 从黑曲霉AU0847中分离得到了一高亲和性、 高催化活性的 $\beta$-葡萄糖苷酶; Winotapum 等 ${ }^{[10]}$ 用一种商 业化的纤维素酶将植物细胞破壁、京尼平苷转化为京尼 平整合为一步进行; $\mathrm{Fu}$ 等 ${ }^{[11]}$ 使用灰绿曲霉转化纯京尼 平苷, 转化率可达 $97.7 \%$, 但是这些方法需要制备纯酶或 者纯京尼平苷, 过程复杂, 成本高. 而且一些商业化的 $\beta$ 葡萄糖苷酶容易和京尼平反应生成最大波长为 $580 \mathrm{~nm}$ 的蓝色素, 从而影响京尼平的收率 ${ }^{[12,13]}$.

微生物直接转化药材的新方法具有成本低、操作简
便的特点, 具有较好的应用前景, 本实验室已成功将其 用于米曲霉转化虎杖制备白藜芦醇和利用米曲霉、哈茨 木霉转化盾叶薯蓣制备薯蓣㒵苷元中 ${ }^{[14,15]}, \mathrm{Xu}$ 等 ${ }^{[16]}$ 报到 用Penicillium nigrican转化京尼平苷制备京尼平, 转化率 可达 $95 \%$, 但发酵时间 $(108 \mathrm{~h}$ )较长, 京尼平苷的转化率是 按照其减少量计算而得的, 且没有京尼平的收率信息, 而这些信息对于评估该方法的应用意义重大. 同时, 该 研究也没有给出转化中关键酶的信息, 它对于阐明生物 转化的机理具有十分重要的意义. 在篎选具有转化枚子 中京尼平苷为京尼平活性的真菌实验中, 我们发现利用 哈茨木霉CGMCC 2979 对栃子中京尼平苷进行生物转 化, 获得的京尼平含量是已知微生物转化药材研究中最 高的 ${ }^{[16]}$. 本文报道了哈茨木需CGMCC 2979发酵(图示 1) 条件优化和京尼平分离纯化方法, 以及哈茨木霉 CGMCC 2979产生的京尼平苷- $\beta$-葡萄糖苷酶的分离、纯 化以及其酶学特征.

\section{2. 实验部分}

\section{1. 材料和试剂}

本文所有的实验都重复了三次, 数据是三次实验的 平均值.

枙子干燥果实(DFA)购自河北省安国, 经粉碎过 60 目篮后用于生物转化. 京尼平苷和京尼平的标准品购自 中药固体制剂制造技术国家药物工程中心(南昌), 纯度 大于 $98.5 \%$. SDS-PAGE蛋白标准品购自宝生物 (大津, 日本), 盾叶新苷、三角叶㿝苷、薯蓣㿝苷元-三葡萄糖苷、 薯蓣㿝苷元-二糖苷标准品由本实验室按照文献[17]制 备, 薯蓣㿝苷元标准品购自Sigma公司(圣路易斯, 美国), 延龄草次苷购自芜湖delta制药公司(芜湖). 大孔吸附树 脂XAD-16N和硅胶分别购自Rohmhass公司(费城, 美国) 和青岛海洋化工公司 (青岛). DEAE Sepharose ${ }^{\mathrm{TM}}$ 和 Superdex 200均购自GE healthcare biosciences公司(匹斯 堡, 美国). $p$-ntirophenyl- $\beta$-glucopyranoside (pNPG)购于 
上海保曼生物技术公司(上海). 其它的化学品均是分析 纯. 用于生物转化的Trichoderma harzianum菌株分离自 本地土壤, 保存于中国普通微生物菌种保藏管理中心 (北京), 编号为:CGMCC 2979.

\section{2. 分析方法}

HPLC(Waters公司, 米尔福德, 美国)由600E液体输 送系统、7725i进样器, 2487型UV检测器组成. 京尼平苷 和京尼平的分析使用Sunfire $\mathrm{C}_{18}$ 柱 $(150 \mathrm{~mm} \times 4.6 \mathrm{~mm} \times 5$ $\mu \mathrm{m}$, 美国Waters公司)在室温下进行. 洗脱条件为乙腈/ 水 $(15: 85 \mathrm{v} / \mathrm{v})$, 流速 $1.0 \mathrm{~mL} / \mathrm{min}$, 检测波长为 $238 \mathrm{~nm}$, 京尼 平苷和京尼平的保留时间分别为 6.14 和 $12.45 \mathrm{~min}$. 甾体 皇苷的分析方法参见文献[18], 使用乙腈(A)和水(B)作 为流动相, 流速为 $1.0 \mathrm{~mL} / \mathrm{min}$, 洗脱条件为: 0-14 min, $44 \% \mathrm{~A} \rightarrow 75 \% \mathrm{~A} ; 14-15 \mathrm{~min}, 75 \% \mathrm{~A} \rightarrow 91 \% \mathrm{~A} ; 15-32$ $\min , 91 \% \mathrm{~A}$. 检测波长为 $203 \mathrm{~nm}$, 盾叶新苷、三角叶皇 苷、薯蓣㿝苷元-三葡萄糖苷、薯蓣㿝苷元-二糖苷、延 龄草次苷和薯蓣皇苷元的保留时间分别为 $7.40,8.95$, 10.10, 11.87, 15.4和30.04 min.

蛋白质浓度采用bradford法测定, 用牛血清白蛋白 作为标准品; $\beta$ - 葡萄糖苷酶的活性采用对硝基苯 (pNPG) 为底物的比色法测定 ${ }^{[19]}, 1$ 单位酶活定义为每小 时释放 1 摩尔 $\mathrm{pNPG}$ 的酶量. $\beta$-葡萄糖苷酶对京尼平苷的 活性按照如下方法测定：取 $0.2 \mathrm{~mL}$ 京尼平苷溶液(1 $\mathrm{mg} / \mathrm{mL}$ ), 和 $0.2 \mathrm{~mL}$ 酶液培养 $2 \mathrm{~h}$ 后, 将样品煮沸 $5 \mathrm{~min}$ 终止 反应, 反应产物由上述HPLC方法定量分析. 酶的分子量 先由SDS-PAGE估算, 然后用MALDI/TOF确定(MALDI, microMXWaters, 美国热电, 沃尔瑟姆, 美国), 纯化后的 京尼平由三重四极杆质谱(Finnigan, TSQ, 美国热电)和 核磁共振仪(INOVA400, 瓦里安公司, 帕罗奥图, 美国) 验证结构.

\section{3. 提取京尼平苷和京尼平}

精确称取约 $3.0 \mathrm{~g}$ 的 DFA 粉末, 分别加入 $0,20 \%$, $50 \%, 70 \%$ 或 $100 \%$ 的乙醇水溶液 $100 \mathrm{~mL}$, 室温静置 $12 \mathrm{~h}$. 索氏提取DFA采用 $20 \%$ 乙醇水溶液, 提取时间为 $4 \mathrm{~h}$. 上 述提取液过滤除去残渣后, 进行HPLC定量分析确定含 量. 为了验证京尼平在优化乙醇浓度下的提取率, 精确 称量 $4.0 \mathrm{mg}$ 京尼平标准品, 溶于 $1 \mathrm{~mL}$ 优化的乙醇溶液中, 京尼平的含量也由HPLC测定.

\section{4. 培养和培养条件优化}

除非特别标明, 所有的液体培养均在 $250 \mathrm{~mL}$ 三角瓶 中进行, 哈茨木霉CGMCC 2979在PDA培养基上培养至 孢子生长旺盛后, 溶于无菌水. 孢子悬液接入含有 $50 \mathrm{~mL}$
$40 \mathrm{~g} / \mathrm{L} \mathrm{DFA}$ 的种子培养基中, 在摇床上 $150 \mathrm{r} / \mathrm{min}$ 振荡培 养 $24 \mathrm{~h}$ 后, 取 $2 \mathrm{~mL}$ 种子液加入到 $50 \mathrm{~mL}$ 新鲜培养基中发 酵培养. 发酵培养基只含有DFA水或DFA磷酸缓冲液, DFA的载量为 $40 \mathrm{~g} / \mathrm{L}$. 所有的种子和发酵培养基均预先 在 $121^{\circ} \mathrm{C}$ 灭菌 $20 \mathrm{~min}$ 以防止DFA中微生物的污染. 培养 中, 每 $4 \mathrm{~h}$ 取样, 菌液中加入 $0.4 \%$ 台酚蓝溶液, 在血细胞 计数器中计算微生物细胞的死亡率, 并测定发酵液中 $\beta-$ 葡萄糖苷酶的活性, 同时将微生物的形态与哈茨木霉 CGMCC 2979纯培养物进行对比, 以保证无其它微生物 污染. 培养 $96 \mathrm{~h}$ 后, 加入 $12.5 \mathrm{~mL}$ 乙醇, 混匀后室温静置 $12 \mathrm{~h}$, 提取液过滤后进行HPLC分析.

为了获得最高收率的京尼平, 对影响转化率的影响 因素(包括发酵时间, DFA浓度、发酵的温度和 $\mathrm{pH}$ )进行 了优化. 发酵时间优化范围为 12-120 h, DFA 载量 $40-120 \mathrm{~g} / \mathrm{L}$, 发酵温度设定为 $25,30,37^{\circ} \mathrm{C}, \mathrm{pH}$ 值范围为 2.1-7.1, 采用 $66.7 \mathrm{mmol} / \mathrm{L}$ 磷酸缓冲液体系.

京尼平的转化率按照下面的公式计算:

收率 $(\mathrm{mg} / \mathrm{g})=$ 转化后京尼平含量 $(\mathrm{mg}) /$ 转化前药材 加入量 $(\mathrm{g})$

转化率 $(\%)=$ 转化后京尼平的含量 $(\mathrm{mol})$ /转化前京 尼平苷的含量 $(\mathrm{mol})$

\section{5. 从发酵液中分离纯化京尼平}

收集发酵 $45 \mathrm{~h}$ 的发酵液加入乙醇至终浓度为 $20 \%$, 提取液在 $10000 \times \mathrm{g}$ 下离心 $20 \mathrm{~min}$, 除去菌体. 上清液命 名为 $45-\mathrm{h}$ 样品. HPLC分析表明, 该样品含有 $2.4 \mathrm{mg} / \mathrm{mL}$ 京尼平和 $0.9 \mathrm{mg} / \mathrm{mL}$ 京尼平苷, 该样品进行XAD-16N树 脂和硅胶层析.

XAD-16N树脂的处理方法为: 干树脂中加入 $95 \%$ 乙醇中振荡 $24 \mathrm{~h}$, 用去离子水充分洗涤备用. XAD- $16 \mathrm{~N}$ 树脂的吸附条件由如下方法确定: 取八份 $10 \mathrm{~mL} 45-\mathrm{h}$ 样 品, $\mathrm{pH}$ 分别调至2.0-9.0后, 倒入 $50 \mathrm{~mL}$ 三角瓶中. 向每个 三角瓶中加入 $1 \mathrm{~g}$ 处理好树脂, $25^{\circ} \mathrm{C}$ 下, 摇床中 $130 \mathrm{r} / \mathrm{min}$ 条件下振荡 $12 \mathrm{~h}$. 树脂吸附样品后, 弃去水相, 用去离子 水洗涤树脂, 然后加入 $10 \mathrm{~mL} 80 \%$ 乙醇水溶液, 在相同转 速和温度下, 再振荡 $12 \mathrm{~h}$. 乙醇洗脱液使用HPLC分析京 尼平苷和京尼平含量, 以确定它们在树脂XAD- $16 \mathrm{~N}$ 上的 吸附量, 其计算公式如下: ${ }^{[20]}$

$$
q_{\mathrm{e}}=\left(C_{0}-C_{\mathrm{e}}\right) \times V_{i} /((1-M) \times W)
$$

$C_{0}$ 和 $C_{\mathrm{e}}$ 分别是京尼平的初始和吸附平衡点的浓度 $(\mathrm{mg} / \mathrm{mL}), V_{i}$ 是溶液的体积 $(\mathrm{mL}), M$ 是含水量 $(\%)$, 按照文 献[20]的方法确定本文中 $M$ 值为 $65 \%, W$ 是树脂的重量 (g). 
采用动态吸附法考察乙醇浓度对京尼平吸附率的 影响, 玻璃色谱柱 $(2.1 \mathrm{~cm} \times 15 \mathrm{~cm}$ ) 装入 $45 \mathrm{~g}$ (湿重) $\mathrm{XAD}-16 \mathrm{~N}$ 树脂, 床体积为 $50 \mathrm{~mL}$. 将 $100 \mathrm{~mL} 45-\mathrm{h}$ 样品调 至pH 4.0 后上柱, 吸附达到平衡后, 用3倍柱体积的去离 子水洗涤, 然后用 $100 \mathrm{~mL}$ 不同浓度的乙醇水溶液 $(30 \%$, $40 \%, 50 \%, 60 \%, 70 \%, 80 \%, 90 \%$ 和 $100 \%$ ) 阶梯梯度洗脱, 洗脱液进行HPLC分析.

硅胶柱层析在装有 $40 \mathrm{~g}$ 硅胶的玻璃色谱柱 $(2.1 \mathrm{~cm} \times$ $24 \mathrm{~cm}$ )中进行, 将 $30 \mathrm{~mL}$ 45-h样品减压浓缩成浸亳, 取 $50 \mathrm{mg}$ 浸膏上样, 硅胶柱用不同比例的氯仿-甲醇溶液 $85: 15$, 84:16, 83:17, 82:18)洗脱, 洗脱液用HPLC分析.

在确定的XAD-16N树脂和硅胶层析条件的基础上, 转化后京尼平采用如下方法纯化: 取京尼平转化率最高 $(48 \mathrm{~h})$ 的样品 $200 \mathrm{~mL}$, 用 $50 \mathrm{~mL}$ 乙醇提取 $12 \mathrm{~h}$ 后, $10000 \times \mathrm{g}$ 离心 $20 \mathrm{~min}$, 得到 $240 \mathrm{~mL}$ 上清液. 上清液含有 $2.6 \mathrm{mg} / \mathrm{mL}$ 京尼平和 $0.09 \mathrm{mg} / \mathrm{mL}$ 京尼平苷(HPLC检测), 该样品命名 为 48-h样品. 该样品调 $\mathrm{pH}$ 至 4.0 后, 上样至装有 $145 \mathrm{~g}$ XAD- $16 \mathrm{~N}$ 的色谱柱中 $(3.0 \mathrm{~cm} \times 30 \mathrm{~cm})$, 色谱柱首先用 2 倍体积 $30 \%$ 乙醇水溶液 $(\mathrm{pH} 4.0$ ) 洗涤, 再用 2 倍体积 $60 \%$ 乙 醇水溶液 (pH 6.5)洗脱, 洗脱液用UV检测器检测收集, 减压浓缩成浸亳. 在色谱柱 $(4.0 \mathrm{~cm} \times 25 \mathrm{~cm})$ 中装入 150 $\mathrm{g}$ 硅胶, 将浓缩的浸膏用少量甲醇溶解后上样, 色谱柱用 $600 \mathrm{~mL}$ 氯仿-甲醇(83:17)洗脱. 含有京尼平的馏分浓缩 至干, 用 $2.0 \mathrm{~mL}$ 甲醇水溶液 $(66.7 \%)$ 洗涤后, 得到纯的京 尼平.

\section{6. 纯化 $\beta$-葡萄糖苷酶}

在最优条件下获得的发酵液, $10000 \times \mathrm{g}$ 离心 $10 \mathrm{~min}$ 去除菌体. 缓慢加入固体硫酸铵至 $75 \%$ 饱和度, 于 $4{ }^{\circ} \mathrm{C}$ 放置过夜, $10000 \times \mathrm{g}$ 离心 $10 \mathrm{~min}$, 收集蛋白沉淀. 粗蛋白 溶于 $66.7 \mathrm{mmol} / \mathrm{L}$ 磷酸钠缓冲液 (pH 5.0) 去除不溶物 $(10000 \times \mathrm{g}, 10 \mathrm{~min})$. 上清液先后用 $0.45 \mu \mathrm{m}$ 膜过滤和超 滤浓缩. 样品上样至DEAE Sepharose色谱柱 $(3.0 \mathrm{~cm} \times$ $12 \mathrm{~cm})$, 该柱预先用上述磷酸钠缓冲液平衡. 收集未结 合馏分, 超滤浓缩后, 上样至Superdex 200 柱 $(3.0 \mathrm{~cm} \times$ $21 \mathrm{~cm}$ ), 该柱也预先用磷酸钠缓冲液平衡, 用相同缓冲 液洗脱, 流速为 $1 \mathrm{~mL} / \mathrm{min}$. 色谱过程中采用 $280 \mathrm{~nm}$ 检测 蛋白, 所有馏分均进行 $\beta$-葡萄糖苷酶活性分析.

\section{7. 酶学特性}

酶学特性主要考察了温度 $\left(20-70{ }^{\circ} \mathrm{C}\right), \mathrm{pH}(2.0-7.0$, $66.7 \mathrm{mmol} / \mathrm{L}$ 磷酸钠缓冲液) 对酶活的影响. 同时进行了 500-800 nm的扫描考察副产物(蓝色素)的生成.

底物特异性实验选用㭛子中京尼平苷和盾叶薯蓣
中甾体㿝苷, 包括盾叶新苷、三角叶皇苷、薯蓣㿝苷元三葡萄糖苷、薯蓣㿝苷元-二糖苷、延龄草次苷. 底物溶 液是将 $1 \mathrm{mg}$ 京尼平苷或甾体皇苷溶于 $1 \mathrm{~mL}$ 磷酸钠缓冲 液, 加入 $0.2 \mathrm{~mL}$ 纯酶液, 对于甾体㿝苷, 反应在 $50^{\circ} \mathrm{C}$ 进行 $24 \mathrm{~h}$, 加入 $0.2 \mathrm{~mL}$ 正丁醇, 涡旋 $1 \mathrm{~min}$, 底物和产物被提取 至丁醇相进行 HPLC检测. 对京尼平苷, 反应也在 $50{ }^{\circ} \mathrm{C}$ 下进行, 反应时间为 $1.0,1.5,2.0,2.5$ 和 $3.0 \mathrm{~h}$, 水中 加热 5 min终止反应.

纯化的京尼平苷- $\beta$-葡萄糖苷酶的 $K_{\mathrm{m}}$ 和 $V_{\max }$ 值, 用 Lineweaver-Burk曲线获得, 测定条件为 $50{ }^{\circ} \mathrm{C}, \mathrm{pH} 5.0$, 底 物京尼平苷浓度为 $1.18-2.95 \mathrm{mmol} / \mathrm{L}$.

\section{3. 结果与讨论}

\subsection{DFA 中京尼平苷含量的确定以及乙醇浓度对京尼 平苷的影响.}

索氏提取实验显示, 京尼平苷在DFA中的含量是 $64.1 \pm 1.5 \mathrm{mg} / \mathrm{g}$, 溶剂提取后, 京尼平苷浓度与该值比较 以确定提取率. 为了确定京尼平苷和京尼平提取物均有 效的方法, 进行了乙醇对京尼平苷和京尼平收率影响的 研究. 研究表明, 京尼平苷主要以固体形式存在于枚子 果实中, 而生物转化后会被分泌到上清中 ${ }^{[16]}$, 所以我们 选用DFA和京尼平的标准品作为提取对象. 使用 $0 \%$, $20 \%, 50 \%, 70 \%$ 和 $100 \%$ 乙醇水溶液提取 DFA 中京尼平 苷的收率分别为 $55.4 \pm 0.8,63.8 \pm 2.4,61.9 \pm 2.9,51.6 \pm$ 0.5 和 $26.8 \pm 1.3 \mathrm{mg} / \mathrm{g}$ DFA. 使用 $20 \%$ 乙醇提取时收率最 高, 与索氏提取法相同(提取率为 $99.5 \%$ ). 用 $20 \%$ 乙醇溶 液提取 $4 \mathrm{mg} / \mathrm{mL}$ 的京尼平标准品, 京尼平的收率达 $99.4 \pm$ $0.2 \%$. 因此, 生物转化前后的样品均加入乙醇至终浓度 为 $20 \%$.

\section{2. 哈茨木霉CGMCC 2979生物转化枚子中京尼平苷}

哈茨木霉 CGMCC 2979接入含DFA粉末的培养基 中, 于 $30^{\circ} \mathrm{C}$ 培养 $96 \mathrm{~h}$ 后, 京尼平苷和京尼平浓度分析显 示, $93 \%$ 的京尼平苷转化为京尼平. 这表明哈茨木霉 CGMCC 2979可以直接转化含有DFA的枚子, 无需酶的 纯化或者从药材中提取京尼平苷的步骤. 在发酵过程 中, 哈茨木需分泌的 $\beta$-葡萄糖苷酶可以水解枙子果实中 的京尼平苷, 副产物为葡萄糖. 而后者可作为真菌的碳 源, 从而减少了由葡萄糖积累导致的负反馈, 使得生物 转化的效率提高.

为了获得更高的收率并缩短发酵时间, 进行了发酵 条件的优化. 培养温度影响实验结果显示, 25,30 和 $37{ }^{\circ} \mathrm{C}$ 时转化率分别为 $92.6 \% \pm 3.7 \%, 97.7 \% \pm 0.9 \%$ 和 $88.6 \pm$ 
$2.2 \%$, 可见, $30^{\circ} \mathrm{C}$ 为获得京尼平的最佳温度, 该温度也 最适合哈茨木霉的生长 ${ }^{[15,21]}$, 京尼平的产生和微生物生 长之间关系密切.

DFA的载量对转化率影响也较大(图1(a)), 京尼平苷 载量为 40 到 $80 \mathrm{~g} / \mathrm{L}$ 时, 京尼平的转化率可以超过 $95 \%$, 如 果超过 $80 \mathrm{~g} / \mathrm{L}$, 转化率则会大幅度降低.

另一个重要影响因素是培养基的 $\mathrm{pH}$ 值(图1(b)). 当 培养基的 $\mathrm{pH}=2.1-5.1$ 时, 转化率低于 $60 \%$; 至6.1时, 转 化率增加到了 $98.3 \% \pm 3.1 \%$; 继续提高 $\mathrm{pH}$ 至 7.1 , 转化率 将降低. 可见, $\mathrm{pH}=6.1$ 最适于微生物产生转化京尼平苷 为京尼平的 $\beta$-葡萄糖苷酶, 同时 $\mathrm{pH} 6.1$ 磷酸缓冲液不仅 能够稳定培养基的 $\mathrm{pH}$ 值, 还能为微生物提供磷源, 促进 微生物的生长和酶的分泌.

经优化, 确定最佳培养条件为DFA载量 $80 \mathrm{~g} / \mathrm{L}, 30^{\circ} \mathrm{C}$ 以及pH 6.1. 该培养条件培养基配方简单, 主要利用药 材中有效成分, 不需要额外补充碳源和氮源, 整个转化 过程简便、高效. 上述优化培养条件的时间进程实验表 明, 京尼平的转化率在 24 到 $48 \mathrm{~h}$ 快速提高, 同时生物转化 前京尼平苷的含量为 $13.2 \mathrm{mmol} / \mathrm{L}$, 在生物转化初期, 随 着发酵进行缓慢降低, $40 \mathrm{~h}$ 以后急速下降. 在 $48 \mathrm{~h}$ 京尼平 的含量达到最高值 $12.9 \mathrm{mmol} / \mathrm{L}(3.0 \mathrm{~g} / \mathrm{L})$, 是Penicillium nigricans 转化获得京尼平的 1.88 倍 $(6.88 \mathrm{mmol} / \mathrm{L}, 1.6 \mathrm{~g} / \mathrm{L})$, 转化率和收率分别为 $97.8 \%$ 和 $3.6 \mathrm{mg} / \mathrm{g} \mathrm{DFA}$ (图2). 发酵 时间文献报道的缩短了 $55.6 \%{ }^{[14]}$; 超过了 $48 \mathrm{~h}$, 转化率逐 渐降低 $(50 \mathrm{~h}$ 为 $91.4 \% \pm 1.3 \%, 52 \mathrm{~h}$ 为 $85.5 \% \pm 4.8 \%, 55 \mathrm{~h}$ 为 $83.6 \% \pm 3.3 \%)$.

台酚蓝染色实验表明发酵最初的 $32 \mathrm{~h}$, 细胞的死亡 率低于 $10 \%, 40$ 和 $48 \mathrm{~h}$ 分别增加到 $13.0 \%$ 和 $16.6 \%$, 但发酵 终止时 $(55 \mathrm{~h})$ 细胞死亡率提高到了 $25.0 \%$. 时间进程中 $\beta-$ 糖苷酶活性显示, $\beta$-糖苷酶活性最初是在 $12 \mathrm{~h}$ 被检测出, 然后在 $40 \mathrm{~h}$ 达到最佳值 $(23.77 \mathrm{U} / \mathrm{mL}), 55 \mathrm{~h}$ 下降到 19.76 $\mathrm{U} / \mathrm{mL}$ (图2). 发酵液的菌体形态观察显示, 发酵液的菌 体和哈茨木霉CGMCC 2979的形态一致. 结果表明, 转 化京尼平苷为京尼平的 $\beta$-葡萄糖苷酶确是由哈茨木霉 CGMCC 2979产生, 而40 h 酶活下降可能与部分真菌细 胞死亡有关.

\section{3. 从发酵液中分离纯化京尼平}

静态吸附实验(图3(a))表明京尼平可以被XAD-16N 吸附, 吸附能力受初始 $\mathrm{pH}$ 影响. 当初始 $\mathrm{pH}$ 从2.0增加到 4.0 过程中, $\mathrm{XAD}-16 \mathrm{~N}$ 对京尼平的吸附量 $q_{\mathrm{e}}$ 逐渐增加, 进 一步增加 $\mathrm{pH}$ 值, 吸附量略有降低; 至7.0, 洗脱液中未能 检测到京尼平, 表明此时京尼平不能被吸附到XAD-16N
上, 所以 $\mathrm{pH}=4.0$ 最适于 $\mathrm{XAD}-16 \mathrm{~N}$ 吸附京尼平. 而在 $\mathrm{pH}$ $=2.0-7.0$ 范围内, XAD-16N对京尼平苷的吸附量一直保 持在约 $3.2 \mathrm{mg} / \mathrm{g}$ 树脂.

从XAD-16N树脂柱上洗脱京尼平, 可以通过阶段提 高乙醇浓度梯度的方式实现. 动态吸附曲线(图3(b))表 明, 洗脱液中京尼平浓度随着洗脱剂中乙醇的含量增加 而增加, 至 $50 \%$ 时, 达到最大值; 继续增加乙醇浓度, 洗 脱液中京尼平的浓度开始下降. 为了获得最大的京尼平 纯化收率和相对高的除杂作用, 洗脱条件为: 色谱柱首 先用 $30 \%$ 乙醇水溶液洗脱除去京尼平苷, 然后用 $60 \%$ 乙 醇水溶液洗脱获得京尼平. 京尼平和京尼平苷的收率分 别为 $92.2 \%$ 和 $32.7 \%$. 结果表明, 当上样条件为 $20 \%$ 乙醇 水溶液 ( $\mathrm{pH} 4.0)$ 时, 绝大部分的京尼平苷不能被 $\mathrm{XAD}-16 \mathrm{~N}$ 吸附, 或者被 $30 \%$ 乙醇水溶液 $(\mathrm{pH} 4.0)$ 的溶液 在洗涤时除去.

因为发酵液中成分比较复杂, 为了获得高纯度京尼 平, 硅胶柱层析也被用于京尼平和京尼平苷的分离纯化. 结果显示, 吸附到硅胶柱上的京尼平苷可以被 $82: 18$ $(v / v)$ 甲醇-氯仿洗脱除去, 而京尼平则主要在83:17 $(v / v)$ 甲醇-氯仿馏分中, 所以 83:17 $(v / v)$ 的甲醇-氯仿被用作京 尼平的洗脱条件.

接着, 将上述得到的最优条件用于纯化 $48 \mathrm{~h}$ 的发酵 液, 此时京尼平苷转化为京尼平的收率最高. 采用 $\mathrm{XAD}-16 \mathrm{~N}$ 树脂和硅胶层析偶联的分离、纯化方式, 可以 有效地去除未转化的京尼平苷、色素和发酵液中其它杂 质, 从 $200 \mathrm{~mL}$ 发酵液中共得到 $389.0 \mathrm{mg}$ 无色的京尼平, HPLC分析显示其纯度为 $98.3 \%$. XAD-16N和硅胶层析 的收率分别为 $87.1 \%$ 和 $77.0 \%$, 纯化的总收率为 $62.3 \%$.

质谱分析显示, 纯化的产物在负离子模式下有两个 离子峰, 225 和 261 分别代表 $[\mathrm{M}-\mathrm{H}]^{-}$和 $[\mathrm{M}+\mathrm{Cl}]^{-}$, 所以分 离得到的化合物分子量为 226 , 与京尼平的一致. 其核磁 共振的数据如下: ${ }^{1} \mathrm{H} \mathrm{NMR}\left(\mathrm{CH}_{3} \mathrm{OD}\right) \delta: 7.53(\mathrm{~s}, \mathrm{H}-3)$, $5.83(\mathrm{~s}, \mathrm{H}-7), 4.80(\mathrm{~d}, J=8.4 \mathrm{~Hz}, \mathrm{H}-1), 4.32(\mathrm{~d}, J=14.4 \mathrm{~Hz}$, H-10a), 4.22(d, $J=14.4 \mathrm{~Hz}, \mathrm{H}-10 \mathrm{~b}), 3.70\left(\mathrm{~s},-\mathrm{OCH}_{3}\right), 3.16$ (m, H-5), 2.86(1H, m, H-6b), 2.50(1H, m, H-9), 2.06(1H, m, H-6a). ${ }^{13} \mathrm{C}$ NMR(400 MHz, $\left.\mathrm{CH}_{3} \mathrm{OD}\right) \delta: 170.0\left(-\mathrm{CO}_{2}-\right)$, 154.4(C-3), 145.7(C-8), 128.4(C-7), 111.9(C-4), 97.9(C-1), 61.8(C-10), 51.8(- $\left.\mathrm{OCH}_{3}\right), 48.6(\mathrm{C}-9), 40.1(\mathrm{C}-6), 37.8(\mathrm{C}-5)$, 与文献[4]报道一致.

据我们所知, 在用微生物直接转化药材的研究中, 哈茨木霉CGMCC 2979转化枚子京尼平苷的发酵时间 最短, 转化率以及得到的京尼平的浓度均最高, 此外采 
用XAD-16N和硅胶还能够很好地选择性分离京尼平和 京尼平苷, 构成了一种高效获得高纯度京尼平的方法.

\section{4. 京尼平苷- $\beta$-葡萄糖苷酶的纯化和酶学性质}

为了研究酶学性质, 首先采用了硫酸铵沉淀、DEAE sepharose和Superdex 200等分离手段对哈茨木霉中京尼 平苷- $\beta$-葡萄糖苷酶进行了纯化. DEAE Sepharose未结 合馏分显示出 $\beta$-葡萄糖苷酶活性, 该馏分经过Superdex 柱层析后获得纯酶, 纯化倍数为 16 倍, 收率为 $14.7 \%$. 使 用 $\mathrm{pNPG}$ 做为底物进行了底物特异性研究, 测定纯化的 京尼平苷- $\beta$-葡萄糖苷酶的活性为 $72.0 \mathrm{U} / \mathrm{mg}$, 酶纯化的 数据见表1.

SDS-PAGE(图4)显示, 纯化京尼平苷- $\beta$-葡萄糖苷酶 的分子量约为 $76.5 \mathrm{kDa}$, MALDI/TOF MS分析显示其准 确分子量为 $74.4 \mathrm{kDa}$, 小于从人小肠厌氧菌和黑曲霉 $\mathrm{Au} 0847$ 中分离的京尼平苷- $\beta$ - 葡萄糖苷酶的 90 和 230 $\mathrm{kDa}^{[9,22]}$.

哈茨木霉中分离得到的京尼平苷- $\beta$ - 葡萄糖苷酶在 pH 4.0-5.0显示最大酶活, pH 6.0 时转化率略有降低, 但 依然达到 $90 \%$ 以上, $\mathrm{pH}$ 达到 7.0 时, 转化率降至 $70 \%$. 该 酶的活性随着温度的升高而升高, 在 $50{ }^{\circ} \mathrm{C}$ 达到最高, $60{ }^{\circ} \mathrm{C}$ 后显著降低, $70^{\circ} \mathrm{C}$ 失去酶活. 时间进程显示, 京尼 平主要在发酵 $40 \mathrm{~h}$ 时产生, 同时也表现出最大 $\beta$-葡萄糖 苷酶酶活. 可见 $0-40 \mathrm{~h}$ 是产酶的阶段, $40-48 \mathrm{~h}$ 是生物转 化的阶段. 在生物转化阶段, 提高发酵温度将缩短生物 转化时间、提高产物收率 ${ }^{[14]}$. 结合该酶的最适温度 $40-50{ }^{\circ} \mathrm{C}$, 可认为在转化阶段 (40-48 h) 可将温度提高到 $40-50^{\circ} \mathrm{C}$, 从而会进一步缩短转化时间, 提高转化效率.

该酶在 $50{ }^{\circ} \mathrm{C}, \mathrm{pH} 5.0$ 的条件下, 经 1 和 $2 \mathrm{~h}$ 可以将 $91.0 \%$ 和 $98.9 \%$ 的京尼平苷转化为京尼平. $K_{\mathrm{m}}$ 和 $V_{\text {max }}$ 值
分别为 $3.6 \mathrm{mmol} / \mathrm{L}$ 和 $775 \mu \mathrm{mol} / \mathrm{h} \mathrm{mg}$ protein $(y=0.00467 x$ $\left.+0.00129, R^{2}=0.9746\right)$, 该酶的 $K_{\mathrm{m}}$ 值和从黑曲霉 $\mathrm{Au} 0847$ 中分离得到的酶的相近 $(2.93 \mathrm{mmol} / \mathrm{L})^{[9]}$. 该酶不能够水 解三角叶皇苷和盾叶新苷的 $\alpha(1 \rightarrow 2)$ 鼠李糖苷键, 以及 不能水解含有 $\beta(1 \rightarrow 3)$ 和 $\beta(1 \rightarrow 4)$ 糖苷键的甾体㿝苷, 如 盾叶新苷, 三角叶㿝苷、薯蓣㿝苷元-三葡萄糖苷、薯蓣 㿝苷元-二匍萄糖苷; 同时也不能水解延龄草次苷, 该化 合物也含有单一的 $\beta-1-4$ 葡萄糖苷键, 但其苷元京尼平苷 的苷元结构不同. 由此可见, 从哈茨木霉中纯化的酶是 一种特异性的京尼平苷- $\beta$-葡萄糖苷酶, 可以特异性识别 京尼平苷的苷元. 一种分子量为 $75 \mathrm{kDa}$ 的 $\beta$-葡萄糖苷曾 经从哈茨木霉中分离出, 底物特异性研究表明, 该酶可 以以一些烷基糖苷、二糖以及寊糖作为底物. 但它以天 然产物为底物的酶学研究未见报道 ${ }^{[23]}$.

扫描500-800 nm范围内吸收光谱发现, 京尼平苷- $\beta$ 葡萄糖苷酶转化京尼平苷前后的吸收光谱未发生明显 变化, 表明纯化的京尼平苷- $\beta$-葡萄糖苷酶不与京尼平反 应. 表现出与普通商业化酶不同的特性, 这可能是该酶 在直接转化药材中京尼平苷时转化率较高的原因之一.

\section{4. 结论}

我们发现了一种简便、高效制备京尼平的方法, 它 采用哈茨木霉CGMCC 2979转化栃子中的京尼平苷, 生 成的京尼平从发酵液中使用XAD-16N和硅胶柱层析分 离, 纯化收率 $62.3 \%$, 纯度 $98.3 \%$. 和以前的同类工作相 比, 该法转化时间最短、收率和京尼平的浓度最高. 另 外, 从哈茨木霉中分离得到的京尼平苷- $\beta$-葡萄糖苷酶对 京尼平苷显示较高的特异性水解的活性. 该方法具有替 代现有京尼平制备方法的潜力. 